\title{
Pengaruh Perbedaan Tekanan Pengepresan terhadap Kualitas Briket Arang Kotoran Sapi
}

Eugenius Belarminus Siki ${ }^{\mathrm{a}}$

${ }^{a}$ Fakultas Pertanian, Universitas Timor, Kefamenanu, TTU - NTT, 85613, Indonesia,email: belarmenus@gmail.com

\section{Article Info}

Article history:

Received 01 Januari 2020

Received in revised form 22 Mei 2020

Accepted 30 Juni 2020

DOI

https://doi.org/10.32938/ja.v5i3.975

\section{Keywords:}

Briket arang

Kotoran sapi

Tekanan pengepresan

\section{Abstrak}

Penelitian ini telah dilaksanakan di laboratorium Fakultas Pertanian Universitas Timor, berlangsung selama 1 bulan terhitung dari 07 Agustus 2019 sampai dengan 05 September 2019. Tujuan dari penelitian ini adalah untuk mengetahui pengaruh perbedaan tekanan pengepresan terhadap kualitas briket arang kotoran sapi. Penelitian ini menggunakan model Rancangan Acak Lengkap (RAL) dengan 4 perlakuan dan masing-masing perlakuan diulang sebanyak 4 kali sehingga terdapat 16 unit percobaan. Komposisi briket tersebut yaitu 95\% kotoran sapi dan tepung kanji 5\% adapun perlakuan yang diuji terdiri dari: $(\mathrm{R} 1)=$ Briket kotoran sapi dengan tekanan pengepresan10 kg/ $\mathrm{cm}^{2}$, (R2): Briket kotoran sapi dengan tekanan pengepresan $20 \mathrm{~kg} / \mathrm{cm}^{2}$, (R3): Briket kotoran sapi dengan tekanan pengepresan $30 \mathrm{~kg} / \mathrm{cm}^{2}$ dan (R4): Briket kotoran sapi dengan tekanan pengepresan $40 \mathrm{~kg} / \mathrm{cm}^{2}$. Hasil sidik ragam menunjukkan bahwa parameter kadar air dan kadar abu tidak menunjukkan pengaruh nyata antar perlakuan sedangkan laju pembakaran dan nilai kalor menunjukkan pengaruh nyata antar perlakuan $(\mathrm{P}<0,05)$. Disimpulkan bahwa kualitas briket terbaik dilihat dari kadar air dan nilai kalor adalah pada perlakuan $\mathrm{R}_{3}$ (Briket kotoran sapi dengan tekanan pengepresan $30 \mathrm{~kg} / \mathrm{cm}^{2}$ ), sedangkan untuk kadar abu dan laju pembakaran terbaik pada perlakuan $\mathrm{R}_{2}$ (Briket kotoran sapi dengan tekanan pengepresan $20 \mathrm{~kg} / \mathrm{cm}^{2}$ ).

\section{Pendahuluan}

Masyarakat Kabupaten Timor Tengah Utara (TTU) pada umumnya bermata pencaharian bertani dan beternak. Beternak sapi merupakan salah satu mata pencaharian yang dijalankan oleh masyarakat TTU. Populasi ternak sap tersebar hampir diseluruh wilayah TTU dan salah satu hasil sampingan dan usaha beternak sapi adalah dalam bentuk limbah feses yang dihasilkan. Limbah kotoran ternak sapi sejauh ini digunakan masyarakat hanya sebagai pupuk untuk tanaman sayur-sayuran, padahal limbah kotoran ternak sapi dapa digunakan untuk bahan baku produk industri dan bahan bakar. Salah satu contoh bahan bakar yang dihasilkan dari limbah kotoran ternak sapi adalah briket.

Briket arang merupakan bahan bakar padat dengan menggunakan pereka dan tekanan, mengandung senyawa karbon, mempunyai nilai kalori yang relatif tinggi dan dapat menyala dalam waktu yang cukup lama. Briket merupakan energi terbarukan yang dapat dibuat secara sederhana baik ditinjau dari seg bahan baku yang digunakan maupun proses pembuatannya. Sehingga briket memiliki potensi yang baik untuk dikembangkan sebagai bahan bakar alternatif (Hiloihdari et al., 2014). Kotoran sapi merupakan substrat yang dianggap paling cocok sebagai sumber pembuat gas bio ataupun bahan bakar, karena substrat tersebut telah mengandung bakteri penghasil gas metan. Kotoran sap menghasilkan kalor sekitar $4000 \mathrm{kal} / \mathrm{g}$ dan gas metan (CH4) yang cukup tinggi. Gas metan merupakan salah satu unsur penting dalam briket yang berfungs sebagai penyulut, yaitu agar briket yang dihasilkan diharapkan mudah terbakar (Pancapalaga, 2008)

Dalam pembuatan briket kotoran sapi sangat diperlukan tekanan pengepresan agar didapatkan kualitas briket yang baik. Proses pembriketan adalah proses pengolahan yang mengalami perlakuan penggerusan, pencampuran bahan baku, pencetakan dan pengeringan pada kondisi tertentu (Purnama et al., 2012), sehingga diperoleh briket yang mempunyai bentuk ukuran fisik dan sifat kimia tertentu. Tujuan dari pembriketan adalah untuk meningkatkan kualitas bahan sebagai bahan bakar, mempermudah penanganan dan transportasi serta mengurangi kehilangan bahan dalam bentuk debu pada proses pengangkutan. Pengepresan (kuat tekan) briket dapat dijadikan patokan/landasan untuk membuat briket yang berkualitas dan tidak mudah rusak atau pecah. Lubis (2011) menyatakan bahwa salah satu faktor yan mempengaruhi sifat briket bioarang adalah tekanan pengepresan. Tekanan pengepresan penting karena Semakin besar tekanan pengepresan yang diberikan maka kualitas briket yang dihasilkan semakin baik. Berdasarkan penelitian Triono (2006) semakin tinggi nilai kuat tekan briket, maka daya tahan briket semakin baik. Perkembangan energi baru dan terbarukan merupakan suatu energi alternatif yang berbahan limbah kotoran ternak sap yang dapat dikembangkan lebih lanjut menjadi bahan bakar padat atau briket yang dapat mengganti bahan bakar minyak tanah dan kayu bakar. Tujuan dari penelitian ini adalah untuk mengetahui pengaruh perbedaan tekanan pengepresan terhadap kualitas briket arang kotoran sapi.

\section{Metode}

\subsection{Lokasi dan Waktu Penelitian}

Penelitian ini telah dilaksanakan pada tanggal 07 Agustus sampai tangga 05 September 2019, bertempat di Fakultas Pertanian Universitas Timor Sedangkan analisis nilai kalor dilakukan pada Laboratorium Ilmu dan Teknologi Pakan, Institut Pertanian Bogor (IPB).

\subsection{Alat dan Bahan}

Alat-alat yang digunakan dalam penelitian ini adalah kiln drum, kuali dan pengaduk, tungku atau kompor, kayu bakar, lesung atau kayu penghancur bahan pembuat briket, ayakan, ember, alat pencetak briket, kamera, dulang plastik, gelas plastik, cawan porselen, cawan alumunium, oven, tanur, desikator, timbangan merk ohause, wajan, sendok, pena, buku, korek api, triplex, dan pemberat. Bahan-bahan yang digunakan adalah arang kotoran sapi, tepung tapioka dan air.

\subsection{Metode Penilitian}

Metode penelitian yang digunakan dalam penelitian ini adalah Rancangan Acak Lengkap (RAL) dengan 4 perlakuan dan masing-masing perlakuan diulang sebanyak 4 kali. Komposisi kedua briket tersebut memiliki masa jenis yang sama (100 gram) dengan $95 \%$ kotoran sapi dan $5 \%$ tepung kanji. Perlakuan yang diuji terdiri dari

$\mathrm{R} 1$ : Briket kotoran sapi dengan tekanan pengepresan $10 \mathrm{~kg} / \mathrm{cm}^{2}$

$\mathrm{R} 2$ : Briket kotoran sapi dengan tekanan pengepresan $20 \mathrm{~kg} / \mathrm{cm}^{2}$

R3 : Briket kotoran sapi dengan tekanan pengepresan $30 \mathrm{~kg} / \mathrm{cm}^{2}$

R4 : Briket kotoran sapi dengan tekanan pengepresan $40 \mathrm{~kg} / \mathrm{cm}^{2}$

\subsection{Prosedur Penelitian}

\subsubsection{Prosedur Pembuatan Arang Kotoran Sapi}

Pembuatan arang kotoran sapi sesuai dengan petunjuk Suding dan Jamaludin (2015) yakni, kotoran sapi dibersihkan dari kotoran lain lalu dimasukkan ke dalam kiln drum (tempat pembakaran) secara terpisah, kemudian dilakukan pembakaran yang dibantu dengan nyala api dari dasar tabung sampai semua kotoran terbakar menjadi arang. Setelah semua bahan terbakar menjadi arang, api di dasar tabung dipadamkan, lalu lubang asap ditutup, sampai api benar-benar padam.

\subsubsection{Prosedur Pembuatan Briket}

Prosedur pembuatan briket ini sesuai dengan petunjuk Sarjono dan Ridlo (2013)

1) Hasil pengarangan ditumbuk menjadi tepung arang

2) Hasil tumbukan kemudian diayak (40 mesh) untuk mendapatkan ukuran yang seragam.

3) Menimbang takaran serbuk kotoran sapi (95\%) dan tepung tapioka (5\%).

4) Membuat perekat dari campuran tepung tapioka yang sudah ditimbang sebelumnya dengan air yang sudah dididihkan.

5) Dilakukan pencampuran antara bahan baku yang sudah disaring dengan perekat tapioka, pencampuran dilakukan hingga adonan merata.

6) Mencetak briket dengan memasukkan adonan kedalam alat cetak yang sudah dibuat sendiri oleh peneliti dengan bentuk cetakan adalah silinder sehingga menghasilkan ukuran briket dengan tinggi $5 \mathrm{~cm}$ dan diameter 6 $\mathrm{cm}$

7) Mengeluarkan hasil cetakan briket kemudian melakukan penimbangan untuk memperoleh berat awal dari briket sebelum dilakukan proses pengeringan

8) Mencatat data briket

9) Briket dikeringkan dengan cara dijemur dibawah sinar matahari selama 4-5 hari.

\subsubsection{Prosedur Pengambilan Data}

Setelah briket selesai dibuat, selanjutnya dihitung kadar air sampel yang ditentukan dengan metode oven, dengan cara menimbang bahan dengan timbangan analisis $5 \mathrm{~g}$ dalam cawan alumunium yang telah diukur bobo keringnya. Kemudian dikeringkan didalam oven pada suhu $105^{\circ} \mathrm{C}$ selama 120 menit sampai beratnya konstan, kemudian bahan didinginkan didalam desikator selama 60 menit dan timbang kembali. Penentuan kadar air akan dilakukan sebanyak empat kali pengulangan.

Kadar abu dalam pengujian diukur dengan cara sampel ditimbang 5 gram dan dimasukkan kedalam cawan porselen, Kemudian diabukan dalam tanur pada suhu $550^{\circ} \mathrm{C}$ selama 120 menit hingga menjadi abu lalu didinginkan di dalam desikator kemudian segera timbang setelah mencapai suhu ruang (Putri dan Andasuryani, 2017). Penentuan kadar abu dilakukan sebanyak empat kal pengulangan. Tahap selanjutnya adalah menghitung laju pembakaran briket yang dihitung dengan cara berat briket yang telah dinyalakan dibagi dengan waktu pembakaran sampai briket habis terbakar atau menjadi abu.

Tahap terakhir menghitung nilai kalor, prosedur kerja untuk menentukan nilai kalor adalah sebagai berikut (Putri dan Andasuryani, 2017) : 
a. Sampel briket dihancurkan dan ditimbang, kemudian dimasukkan kedalam cawan pembakar tepat dibawah lengkungan kawat sumbu yang kedua ujungnya telah dikaitkan pada kedua elektroda.

b. Rangkaian tersebut kemudian dimasukkan kedalam bomb yang sebelumnya telah diisi akuades sebanyak $1 \mathrm{ml}$ kedalam bomb, selanjutnya ditutup rapat dan dialiri gas oksigen melalui katup kurang lebih 35 atm. Bomb dimasukkan kedalam kalorimeter yang telah diisi air sebanyak 2 liter, dan dihubungkan dengan unit pembakar.

c. Kalorimeter ditutup dan termometer dipasang pada tutup kalorimeter, sehingga skala pada bagian bawah tepat pada angka $19^{\circ} \mathrm{C}$, temperatur konstan pengaduk listrik dihidupkan dan dibiarkan selama 5 menit, kemudian sumber tegangan arus 23 volt dihidupkan untuk membakar kawat sumbu. Pada saat ini temperatur diamati maka temperatur akan naik dengan cepat, setelah itu konstan dan akhirnya sedikit akan turun, kemudian sumber tegangan pembakar dan pengaduk dimatikan.

\subsection{Variabel Penelitian}

Variabel yang diukur dalam penelitian ini adalah:

\subsubsection{Kadar air}

Rumus perhitungan kadar air :

$\%$ kadar air $=\frac{b-c}{b-a} \times 100 \%$

Keterangan :

$\mathrm{a}=$ berat cawan kosong $(\mathrm{g})$

$\mathrm{b}=$ berat cawan + sampel briket $(\mathrm{g})$

$\mathrm{c}=$ berat cawan + sampel briket setelah di oven hingga beratnya konstan (g)

\subsubsection{Kadar abu}

Kadar abu dihitung dengan rumus :

$\%$ kadar abu $=\frac{\text { berat } a b u}{\text { berat sampel }} \times 100 \%$

2.5.3 Laju pembakaran briket

Laju pembakaran briket dihitung dengan rumus :

Laju pembakaran briket $=\frac{\text { berat briket }}{\text { waktu sampai briket habis (menit) }}$

2.5.4 Nilai kalor

Kalor merupakan suatu kuantitas atau jumlah panas yang baik yang diserap maupun dilepaskan oleh suatu benda. Nilai kalor diperoleh dari briket dengan data laboratorium. Rumus menghitung nilai kalor adalah sebagai berikut:

$\mathrm{Q}=\mathrm{m} \cdot \mathrm{c} \cdot \Delta \mathrm{T}$

Keterangan :

Q =Panas yang diperlukan untuk menaikkan temperature

$\mathrm{m}=$ Masa bahan bakar

c $\quad=$ Kalor jenis

$\Delta \mathrm{T}=$ Perbedaan temperature

\subsection{Analisis Data}

Data yang diperoleh diolah dengan menggunakan sidik ragam sesuai Rancangan Acak Lengkap (RAL), dan dilakukan uji lanjut dengan menggunakan Uji Jarak Berganda Duncan (Steel dan Torrie, 1991).

Model matematikanya adalah $\mathrm{Yij}=\mu+\tau \mathrm{i}+€ \mathrm{ij}$

Keterangan :

Yij = Nilai pengamatan dengan ulangan ke-j

$\mu \quad=$ Rata-rata umum (nilai tengah pengamatan)

$\tau \mathrm{i}=$ Pengaruh perlakuan ke-i $(\mathrm{i}=1,2,3,4,5,6)$

$€ \mathrm{ij}=$ Galat percobaan dari perlakuan ke-i pada pengamatan ke- $\mathrm{j}(\mathrm{j}=1$, $2,3,4)$

\section{Hasil dan Pembahasan}

\subsection{Kadar Air}

Kadar air adalah kandungan air yang ada dalam briket. Briket arang memiliki sifat higroskopis (mudah menyerap air dari sekelilingnya) yang tinggi. Penghitungan kadar air bertujuan untuk mengetahui sifat higroskopis briket arang hasil penelitian. Pengukuran kadar air briket arang dilakukan setelah dikempa dan dikeringkan dengan nilai rata-rata kadar air dibawah SNI yaitu $8 \%$ (Putri dan Andarsuryani, 2017). Dalam pengujian kadar air pada briket kotoran sapi dengan tekanan $10 \mathrm{~kg} / \mathrm{cm}^{2}, 20 \mathrm{~kg} / \mathrm{cm}^{2}, 30 \mathrm{~kg} / \mathrm{cm}^{2}$ dan $40 \mathrm{~kg} / \mathrm{cm}^{2}$ didapatkan nilai uji kadar air seperti pada Gambar 1.

Gambar 1 menunjukkan persentase kadar air briket kotoran sapi tertinggi pada tekanan pengepresan $20 \mathrm{~kg} / \mathrm{cm}^{2}$ (R2) yaitu sebesar $6,46 \%$ diikuti briket dengan tekanan pengepresan $10 \mathrm{~kg} / \mathrm{cm}^{2}$ (R1) sebesar $6,45 \%$ diikuti lagi dengan tekanan pengepresan $40 \mathrm{~kg} / \mathrm{cm}^{2}(\mathrm{R} 4)$ yaitu sebesar $6,37 \%$ dan kadar air briket kotoran sapi terendah pada tekanan pengepresan $30 \mathrm{~kg} / \mathrm{cm}^{2}(\mathrm{R} 3)$ yaitu sebesar $6,33 \%$.

Hasil uji statistik menunjukkan bahwa briket kotoran ternak sapi tidak berpengaruh nyata terhadap persentase kadar air yang dihasilkan. Dari Gambar 1 terlihat bahwa kadar air terendah pada R3. Menurut Triono (2006), tingginya kadar air disebabkan karena jumlah pori-pori yang lebih banyak. Kadar air sangat berpengaruh terhadap kualitas briket yang dihasilkan, semakin rendah kadar air briket maka akan semakin tinggi nilai kalor dan daya pembakarannya. Kadar air yang tinggi akan membuat briket sulit dinyalakan pada saat pembakaran dan akan banyak menghasilkan asap, selain itu akan mengurangi temperatur penyalaan dan daya pembakarannya (Hutasoit, 2012). Hal ini juga hampir sama dengan penelitian Almu et al. (2014) yang menyatakan bahwa faktor yang menyebabkan perbedaan besarnya persentase kadar air pada masing-masing sampel briket dapat disebabkan karena pengaruh tidak meratanya campuran kanji dan air pada adonan briket saat pencampuran dilakukan sehingga mengalami penyerapan air yang berbeda-beda pada setiap sampel briket. Namun dalam penelitian ini persentase kadar air sudah memenuhi standar nasional indonesia (SNI) yaitu lebih rendah dari 7,57\%.



Gambar 1. Hasil pengujian Kadar Air Briket Kotoran Sapi.

\subsection{Kadar Abu}

Kadar abu merupakan bagian yang tersisa dari hasil pembakaran dalam hal ini abu yang dimaksud adalah abu sisa pembakaran briket. Salah satu penyusun abu adalah silika, pengaruhnya kurang baik terhadap nilai kalor briket arang yang dihasilkan. Kadar abu briket berpengaruh terhadap nilai kalor dan nilai kadar karbon. Semakin kecil nilai kadar abu maka semakin tinggi nilai kalor dan kadar karbonnya (Putri dan Andarsuryani, 2017). Abu adalah mineral yang tak dapat terbakar yang tertinggal setelah proses pembakaran dan perubahan-perubahan atau reaksi-reaksi yang menyertainya. Abu ini dapat menurunkan nilai kalor dan menyebabkan kerak pada peralatan sehingga persentase abu tidak boleh terlalu besar (Febriana et al., 2015). Pengujian kadar abu dapat dilihat pada Gambar 2.

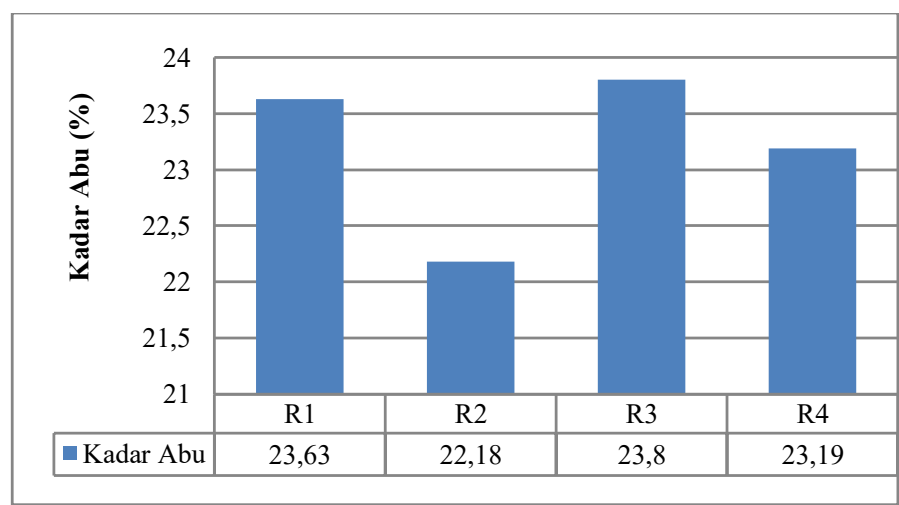

Gambar 2. Hasil Pengujian Kadar Abu Briket Kotoran Sapi.

Gambar 2 menunjukkan persentase kadar abu briket kotoran sapi tertinggi pada tekanan pengepresan $30 \mathrm{~kg} / \mathrm{cm}^{2}$ (R3) yaitu sebesar $23,80 \%$ diikuti briket kotoran sapidengan tekanan pengepresan $10 \mathrm{~kg} / \mathrm{cm}^{2}$ (R1) sebesar $23,63 \%$ diikuti briket kotoran sapi dengan tekanan pengepresan $40 \mathrm{~kg} / \mathrm{cm}^{2}$ (R4) sebesar $23,19 \%$ dan kadar abu terendah pada briket kotoran sapi dengan tekanan pengepresan $20 \mathrm{~kg} / \mathrm{cm}^{2}$ (R2) yaitu sebesar 22,18\%. Hasil uji statistik menunjukkan bahwa briket kotoran ternak sapi tidak berpengaruh nyata terhadap persentase kadar abu yang dihasilkan. Tingginya kadar abu kemungkinan disebabkan pada waktu pengeringan briket terjadi kontak dengan udara sehingga terjadi proses pembakaran lebih lanjut dimana arang aktif yang terbentuk berubah menjadi abu. Chaeriawan (2016), menyatakan bahwa kadar abu yang dihasilkan dipengaruhi oleh campuran bahan yang memiliki kadar abu tinggi. Kadar abu briket yang dihasilkan adalah akumulasi dari bahan yang digunakan. Menurut (Mangkau et al., 2011) bahwa tingginya kadar abu dalam briket disebabkan karena proses karbonasi yang belum optimal. Secara umum briket yang dihasilkan pada penelitian ini memiliki nilai kadar abu yang cukup tinggi namun dan dikategorikan belum memenuhi standar nasional indonesia (SNI) yang mempunyai kadar abu 5,51\%. Faktor jenis bahan bahan baku sangat berpengaruh terhadap tinggi rendahnya kadar abu briket yang dihasilkan.

\subsection{Laju Pembakaran}

Laju pembakaran briket merupakan banyaknya berat briket yang terbakar dalam selang waktu tertentu. Pengujian laju pembakaran dilakukan untuk mengetahui efektifitas dari suatu bahan bakar. Hal ini untuk mengetahui sejauh mana kelayakan dari bahan bakar yang diuji sehingga dalam aplikasinya bisa digunakan. Laju pembakaran briket dipengaruhi oleh faktor nilai kalor dan 
kadar air (Putri dan Andarsuryani, 2017). Pengujian laju pembakaran dapat dilihat pada Gambar 3.

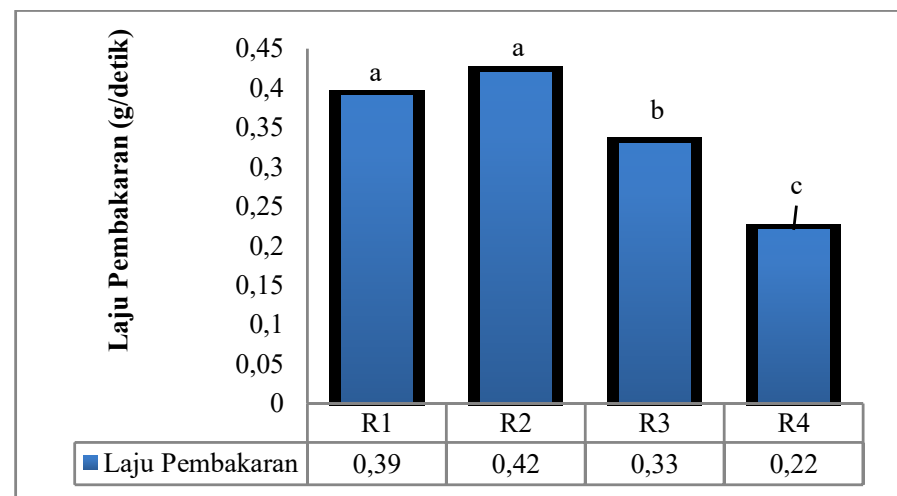

Gambar 3. Hasil Pengujian Laju Pembakaran. Huruf pada bagian atas Gambar yang tidak sama menunjukkan berbeda sangat nyata $(\mathrm{P}<0.05)$ pada $\alpha 0.05$

Gambar 3 menunjukkan proses laju pembakaran briket kotoran sapi terbaik pada tekanan pengepresan $20 \mathrm{~kg} / \mathrm{cm}^{2}$ (R2) yaitu sebesar $0,42 \%$ diikuti briket dengan tekanan pengepresan $10 \mathrm{~kg} / \mathrm{cm}^{2}(\mathrm{R} 1)$ yaitu sebesar $0,39 \%$ diikuti briket dengan tekanan pengepresan $30 \mathrm{~kg} / \mathrm{cm}^{2}$ (R3) sebesar $0,33 \%$ dan laju pembakaran terendah pada briket kotoran sapi dengan tekanan pengepresan 40 $\mathrm{kg} / \mathrm{cm}^{2}$ (R4) yaitu sebesar $0,22 \%$. Hasil uji statistik menunjukkan bahwa perlakuan berpengaruh sangat nyata terhadap laju pembakaran $(\mathrm{P}<0,05)$. Hasil uji duncan menunjukkan bahwa hanya pada pasangan perlakuan R1 dan R2 yang menunjukkan tidak berbeda sedangkan pada pasangan perlakuan lainnyan menunjukkan perbedaan yang sangat nyata. Dari Gambar 3 menunjukkan bahwa semakin tinggi tekanan pengepresan maka laju pembakaran briket akan menurun, hal ini terjadi karena tekanan pengepresan yang tinggi membuat butir-butir briket semakin menyatu dan semakin rapat sehingga hanya sedikit udara yang terjebak di dalam briket serta membuat pori-pori (porositas) briket mengecil. Keadaan ini membuat pada saat briket terbakar, udara yang digunakan untuk pembakaran briket sebagian besar di dapat dari bagian luar briket dan ini masih terhalang dengan abu yang menutupi permukaan briket sehingga membuat laju pembakaran briket menjadi melambat (Nugraha et al., 2017).

\subsection{Nilai Kalor}

Nilai kalor sangat menentukan kualitas briket karena semakin tinggi nilai kalor maka semakin baik kualitas briket yang dihasilkan. Nilai kalor bahan bakar adalah jumlah energi panas maksimum yang dibebaskan oleh suatu bahan bakar melalui reaksi pembakaran sempurna persatuan massa atau volume bahan bakar tesebut. Analisa nilai kalor suatu bahan bakar dimaksudkan untuk memperoleh data tentang energi kalor yang dapat dibebaskan oleh suatu bahan bakar dengan terjadinya reaksi atau proses pembakaran (Almu et al., 2014). Nilai kalor yang didapatkan dari briket kotoran sapi dengan beberapa tekanan pengepresan dapat dilihat pada Gambar 4.

Gambar 4 menunjukkan nilai kalor briket kotoran sapi tertinggi pada tekanan pengepresan $30 \mathrm{~kg} / \mathrm{cm}^{2}$ (R3) sebesar $2849 \mathrm{kal} / \mathrm{g}$ diikuti briket dengan tekanan pengepresan $40 \mathrm{~kg} / \mathrm{cm}^{2}$ (R4) sebesar $2752 \mathrm{kal} / \mathrm{g}$ diikuti briket dengan tekanan pengepresan $20 \mathrm{~kg} / \mathrm{cm}^{2}$ (R2) sebesar $2474 \mathrm{kal} / \mathrm{g}$ dan nilai kalor terendah pada briket kotoran sapi dengan tekanan pengepresan $10 \mathrm{~kg} / \mathrm{cm}^{2}(\mathrm{R} 1)$ yaitu sebesar $2339 \mathrm{kal} / \mathrm{g}$. Hasil uji statistik menunjukkan bahwa perlakuan ini berpengaruh sangat nyata terhadap nilai kalor yang dihasilkan $(\mathrm{P}<0,05)$. Hasil uji duncan menunjukkan bahwa semua pasangan perlakuan menunjukkan perbedaan yang sangat nyata terhadap nilai kalor yang dihasilkan. Dari Gambar 4 dapat dijelaskan bahwa tekanan pengepresan dapat mempengaruhi nilai kalor briket yang dihasilkan. Penurunan nilai kalor briket kotoran sapi pada tekanan $40 \mathrm{~kg} / \mathrm{cm}^{2}$ (R4) menunjukkan bahwa arang kotoran sapi memang memiliki nilai kalor yang rendah. Nilai kalor yang rendah disebabkan oleh kandungan abu yang cukup tinggi pada kotoran sapi, hal ini sesuai dengan (Pratiwi, 2017) yang menyatakan nilai kalor yang rendah disebabkan oleh kandungan abu yang cukup tinggi pada sekam padi. Salah satu unsur utama abu adalah silika dan pengaruhnya kurang baik terhadap nilai kalor yang dihasilkan. Ditinjau dari segi nilai kalor, briket kotoran sapi belum memenuhi Standar Nasional Indonesia (SNI) yaitu 6914,11 kal/gram.

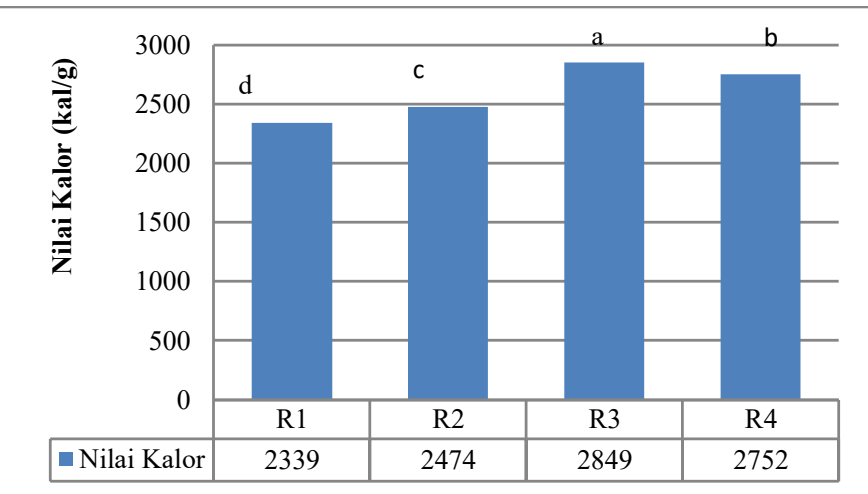

Gambar 4. Hasil Pengujian Nilai Kalor. Huruf pada bagian atas Gambar yang tidak sama menunjukkan berbeda sangat nyata $(\mathrm{P}<0.05)$ pada $\alpha 0.05$

\section{Simpulan}

Dari penelitian ini dapat disimpulkan bahwa kualitas briket terbaik dilihat dari kadar air dan nilai kalor adalah pada perlakuan $\mathrm{R}_{3}$ (Briket kotoran sapi dengan tekanan pengepresan $30 \mathrm{~kg} / \mathrm{cm}^{2}$ ), sedangkan untuk kadar abu dan laju pembakaran terbaik pada perlakuan $\mathrm{R}_{2}$ (Briket kotoran sapi dengan tekanan pengepresan $20 \mathrm{~kg} / \mathrm{cm}^{2}$ ).

\section{Pustaka}

Almu, M. A., Syahrul., Y.A. Padang. 2014. Analisa Nilai Kalor dan Laju Pembakaran pada Briket Campuran Biji Nyamplung (Calophyllm Inophyllum) dan Abu Sekam Padi. Jurnal Dinamika Teknik Mesin, 4 (2) : 117-122.

Chaeriawan, M. A. N. 2016. Pembuatan briket karbon dari campuran ampas tebu dan jerami padi. Skripsi. Departemen Fisika Fakultas Matematika dan Ilmu Pengetahuan Alam Institut Pertanian Bogor. Bogor

Febriana, I., Zurohaina., dan Effendy. S. 2015. Perbandingan Nilai Bakar Briket Batubara dan Briket Arang (Campuran Cangkang Bintaro (Cerbera Manghas) dan Bambu Betung (Dendrocalamus asper). Jurnal Ilmiah TEKNIKA, 6 (1) : 1-10.

Hiloihdari, M., Das. D., dan Baruah. D. C. 2014. Bioenergy Potential from Crop Residue Biomass in India. Renewable and Sustainable Energy Reviews, 32: 504-512.

Hutasoit, Aripin. 2012. Briket Arang dari Pelepah Salak. Skripsi. Fakultas Teknologi Pertanian. Universitas Andalas. Padang.

Lubis, H. A. 2011. Uji Variasi Komposisi Bahan Pembuat Briket Kotoran Sapi dan Limbah Pertanian. Fakultas Pertanian. Universitas Sumatera Utara. Sumatera Utara.

Mangkau, A., A. Rahman., dan G. Bintaro. 2011. Penelitian Nilai Kalor Briket Tongkol Jagung Dengan Berbagai Perbandingan Sekam Padi. Prosiding Hasil Penelitian Fakultas Teknik: Teknik Mesin, 5: 1-10.

Nugraha, Andy., Widodo, A., dan Wahyudi, S.2017. Pengaruh Tekanan Pembriketan dan Persentase Briket Campuran Gambut dan Arang Pelepah Daun Kelapa Sawit Terhadap Karakteristik Pembakaran Briket. Jurnal Rekayasa Mesin, 8 (1): 29-36.

Pancapalaga, W. 2008. Evaluasi Kotoran Sapi dan Limbah Pertanian (Kosap Plus) SebagaiBahan Bakar Alternatif. [diakses tanggal 22 Mei 2020].

Pratiwi, I. N., 2007. Pengaruh tekanan kempa terhadap sifat fisik dan kimia arang briket dengan bahan Campuran serbuk gergaji kayu Jati (Tectona grandis) dan Sekam padi. Tugas Akhir. Universitas Islam Indonesia. Yogyakarta.

Purnama, R. R., Chumaidi, A dan Saleh. A. 2012. Pemanfaatan Limbah Cair CPO Sebagai Perekat pada Pembuatan Briket dari Arang Tandan Kosong Kelapa Sawit. Jurnal Teknik Kimia, 18(3) : 43-53.

Putri, R. Eka., dan Andasuryani, 2017. Studi Mutu Briket Arang Dengan Bahan Baku Limbah Biomassa. Jurnal Teknologi Pertanian Andalas, 21(2) :143-151.

Sarjono dan Ridlo.M. 2013. Studi Eksperimental Penggunaan Kotoran Sapi Sebagai Bahan Bakar Alternatif. Majalah Ilmiah STTR Cepu, Nomor 16 Tahun $11: 12-21$.

Suding dan Jamaludin. 2015. Pengaruh jumlah perekat kanji terhadap lama briket terbakar menjadi abu. Jurnal Chemica, 16 (1) : 27-36.

Steel, R. G. D. dan J. H. Torrie. 1991. Prinsip dan Prosedur Statistika. Diterjemahkan oleh Bambang Sumantri. PT. Gramedia Pustaka Utama. Jakarta.

Triono, A. 2006. Karakteristik Briket Arang dari Campuran Serbuk Gergajian Kayu Afrika (Maesopsis emini Engl.) dan Sengon (Paraserianthes falcataria L.). Skripsi. Bogor: Departemen Hasil Hutan. Fakultas Pertanian. Institut Pertanian Bogor. Bogor. 